\title{
Clinical Evolution and Morbi-mortality in Chagas Disease
}

\section{Edmundo Chapadeiro}

Curso de Pós-graduação em Patologia, Faculdade de Medicina do Triângulo Mineiro, Rua Getúlio Guaritá 130, 38025-440 Uberaba, MG, Brasil

Key words: Chagas disease - morbi-mortality - clinical evolution

The knowledge firstly achieved by Carlos Chagas and his colleagues of the Instituto Oswaldo Cruz, increased with all those acquired to date, allow us to outline the general scheme (modified from Dias \& Coura 1997) of American trypanosomiasis natural history (Figure).

The knowledge of this natural history makes more comprehensible the clinical evolution of the disease, as it will be demonstrated by the reporters of the subject.

The Chagas Disease Control Campaign, together with other conditions, has contributed in a decisive way for the significant reduction of the number of new cases of the disease. Nevertheless, millions of chagasic individuals still live in our country as well as in other ones of Latin America (Moncayo 1993, Schmunis 1997, Dias \& Coura 1997). Only this would be enough to justify the concern with morbidity and mortality due to American trypanosomiasis.

In addition, the current data about morbidity (analyzed either by the number of individuals who acquire the disease or by the number of cases in which trypanosomiasis has arisen), as well as the coefficients or rates of mortality allow the understanding of the severe medicosocial problems continuously generated by the endemic.

In the other hand, the prophylatic and therapeutic measures can explain the significant reduction of morbility and mortality rates in Chagas disease (CD) acute phase in the last years, as it may be confirmed by comparing Chagas references $(1910,1916)$ and Chagas and Villela (1922) with those of Dias (1955), Ferreira (1986) and Dias and Coura (1997).

In order to analyse the morbity and mortality in chronical $\mathrm{CD}$, two facts must be initially remembered: first, in the chronic phase of American trypa-

Fax: +55-34-318.5279.

Received 9 June 1999

Accepted 9 August 1999 nosomiasis, the main lesions are situated in the heart and digestive tract; second, the digestive form of the disease was characterized only in the 50s (Rezende 1956). This last fact may explain the lack of references on digestive manifestations in chronical CD in the first half of century (Chagas 1910, Chagas \& Villela 1922), what reflects on comparative analyses, specially regarding morbidity.

In conclusion, it is clear since the beginning of the studies on $\mathrm{CD}$ that cardiac alterations are the main responsible for morbidity and mortality.

Longitudinal studies as those carried out initially in Bambuí, State of Minas Gerais, Brazil, followed by other more recent ones as those of Macedo (1973) and Dias (1982), allow us to conclude that only half of the individuals infected with T. cruzi show, in the course of their lives, clinical manifestations of CD; among those, only about $50 \%$ die as a direct or indirect result of the infectious course. Mortality is generally high among chagasic individuals who develop chronic cardiopathy, mainly when cardiac failure and/or severe arrythmias occur. Grossly, it means that $25 \%$ of the chagasic individuals (which correspond to 350,000 people in Brazil) are bound to die because of $\mathrm{CD}$. The death official registry service in Brazil indicates that the mortality due to disease is about 6,000 deaths/year, prone to decrease in the last decade. In Latin America, Moncayo (1993) evaluates that 45,000 yearly deaths are due to CD.

In the micro-regions of major endemicity, the death rate due to $\mathrm{CD}$ among adult individuals may reach 200 per 100,000 inhabitants or more. These rates are surely underdimensioned since that a significative number of deaths due to chronical chagasic cardiopathy are registered as either due to non defined causes or lack of medical care or due to other cardiopathies.

Data from the World Bank in 1993 show the enormous social burden as a consequence of $\mathrm{CD}$. This burden is significantly greater than that produced by other tropical diseases prevalent in the Americas. Malaria, schistosomiasis, leishmaniasis, filariasis, oncocercosis and leprosy produce all to- 


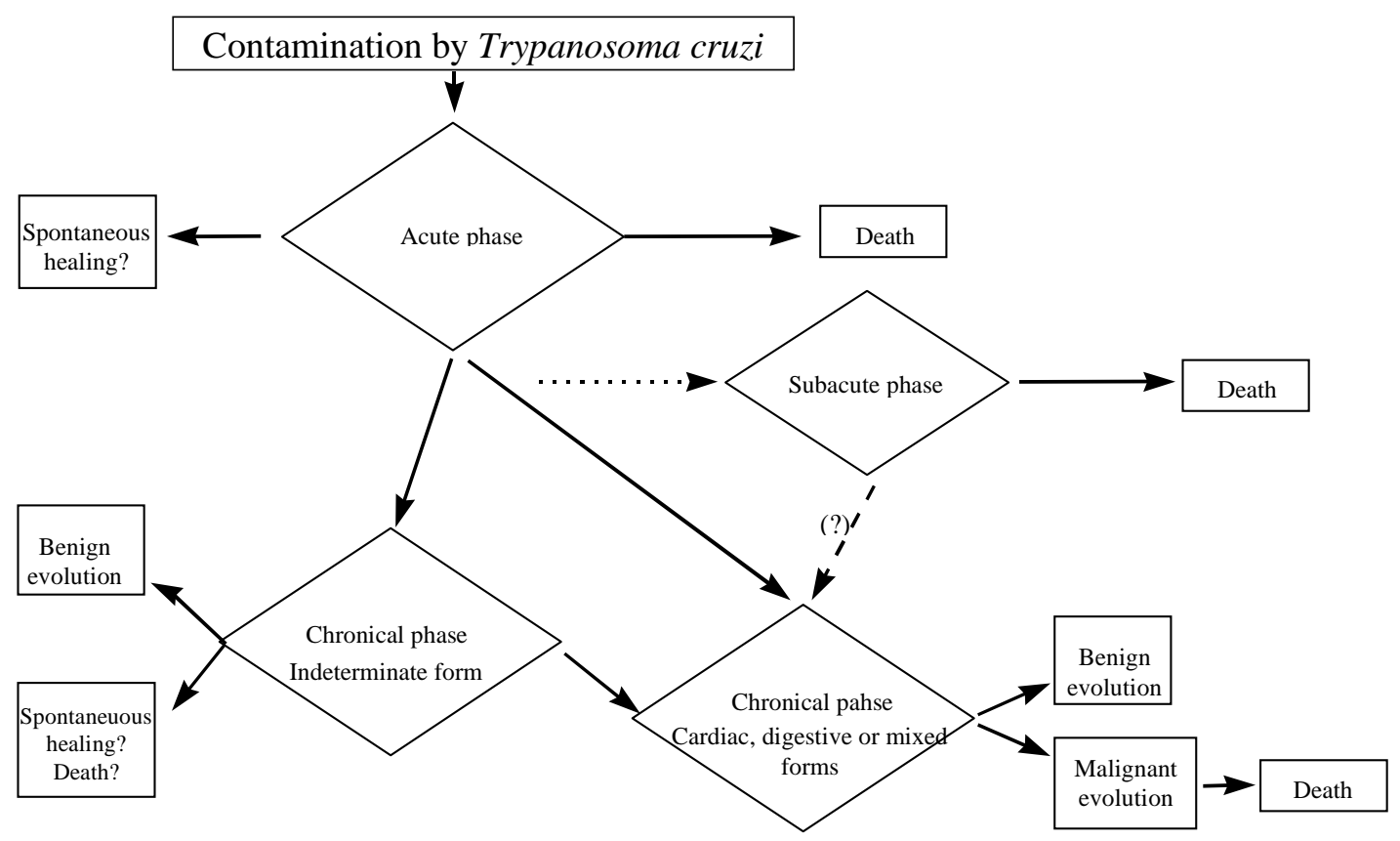

General scheme of natural history of human Chagas disease acquired form (modified from Dias JCP 1990).

gether a burden corresponding to not more than a fourth part of that caused by CD.

The reporters of the morbidity and mortality themes in $\mathrm{CD}$ will treat the subjet more properly and profoundly.

\section{REFERENCES}

Chagas C 1910. Aspecto clinico geral da nova unidade mórbida produzida pelo Schizotrypanum cruzi (nota prévia). Brasil Médico 27: 263-265.

Chagas C 1916. Processos patogênicos da tripanozomiase americana. Mem Inst Oswaldo Cruz 8: 5-35.

Chagas C, Villela E 1922. Forma cardíaca da trypanosomiase americana. Mem Inst Oswaldo Cruz 14: 5-61.

Dias E 1955. Informações acêrca de 300 casos de doença de Chagas com período inicial conhecido fichados no Centro de Estudos de Bambuí. O Hospital 47: 647-658.

Dias JCP 1982. Doença de Chagas em Bambuí, Minas Gerais, Brasil. Estudo Clínico Epidemiológico a Partir da Fase Aguda entre 1940 e 1982, Thesis, Faculdade de Medicina da Universidade Federal de Minas Gerais, Belo Horizonte, 376 pp.

Dias JCP, Coura JR 1997. Epidemiologia, p. 33-65. In JCP Dias \& JR Coura (eds), Clínica e Terapêutica da Doença de Chagas: uma Abordagem Prática para o Clínico Geral, Fundação Oswaldo Cruz, Rio de Janeiro.

Ferreira HO 1968. Forma aguda da doença de Chagas, p. 359-373. In JR Cançado, Doença de Chagas, Imprensa Oficial, Belo Horiozonte.

Macedo VO 1973. Influência da Exposição à Reinfecção na Evolução da Doença de Chagas. Estudo longitudinal de Cinco Anos, Thesis, Faculdade de Medicina, Universidade Federal do Rio de Janeiro, Rio de Janeiro, 125 pp.

Moncayo A 1993. Chagas' disease. Tropical Disease Research. Progress 1991-1992. Eleventh Programme Report of the UNDP/World Bank/WHO Special Programme for Research and Training in Tropical Diseases TRD), p. 67-75. World Health Organization, Geneve.

Rezende SM 1956. Megaesôfago por doença de Chagas. Rev Goiana Med 2: 297-341.

Schmunis GA 1997. Trypanossomiase americana: seu impacto nas Américas e perspectivas de eliminação, p. 11-23. In JCP Dias \& JR Coura, Clínica e Terapêutica da Doença de Chagas: uma Abordagem Prática para o Clínico Geral, Fundação Oswaldo Cruz, Rio de Janeiro.

World Bank 1993. World Development Report 1993. Investing in Health. World Development Indicators, Oxford University Press, Washington. 